ScIDice

\section{Knowledge, Attitude And Practice Towards Teaching On A Virtual Platform Among Private School Teachers In Chennai}

Research Article

Dr.Sarika Balaganesh ${ }^{1}$, Dr.Srisakthi Doraikannan ${ }^{2 *}$,Dr.Meignana Arumugham Indiran ${ }^{3}$

${ }^{1}$ Department of Public Health Dentistry, Saveetha Dental college, Saveetha Institute of Medical and Technical Sciences, Saveetha University No.162, Poonamallee high road, Chennai 600077, Tamil Nadu, India.

${ }^{2}$ Department of Public Health Dentistry, Saveetha Dental college, Saveetha Institute of Medical and Technical Sciences, No.162, Poonamallee high road, Chennai 600077, Tamil Nadu, India.

${ }^{3}$ Department of public health dentistry, Saveetha Dental college, Saveetha Institute of Medical and Technical Sciences, No.162, Poonamallee high road, Chennai 600077, Tamil Nadu, India.

Abstract

Introduction: Digitalization has increased tremendously after the COVID-19 and digital platforms have been used now for education due to the social distancing measures. But the question also arises as to whether the teachers are adapted to rendering classes on a virtual platform. Teachers have a very basic understanding of technology. The necessary resources and tools is often lacking to conduct online classes by the school teachers. The aim of the study is to assess the knowledge, attitude and practice of online teaching among private school teachers in Chennai.

Materials And Methods: This study is a cross-sectional survey and 150 teachers were randomly selected from the private higher secondary schools in Chennai. This study was conducted during the month of January and February 2021. The questionnaire was sent through online platforms to assess the knowledge, attitude and practice regarding teaching on a virtual platform among private school teachers. The statistics was computed in SPSS software 22.0. Descriptive and Chi square tests were used to assess the association between the variables.

Results: Most teachers used Smartphones for conducting the online classes(60\%) and laptop(17\%) and Ipad and tablet devices were also used. $57 \%$ of the teachers used a zoom application to conduct online classes and $20 \%$ used WhatsApp calls for conducting online classes. Google meet, Skype were the other applications used for conducting online classes. There was a significant association between teachers' perspective on virtual teaching and their teaching experience.

Conclusion: The study determined various perspectives from the school teachers about teaching on a virtual platform. The study concluded that $61.3 \%$ had insufficient knowledge and $38.7 \%$ had sufficient knowledge; $44.7 \%$ had negative attitude and $55.7 \%$ had a positive attitude and regarding practice and $42 \%$ of study participants had inadequate practice and 58 had adequate practice on teaching on online platforms.

Keywords: Attitude; Online Teaching; Knowledge,Practice; School Teachers.

\section{Introduction}

The COVID-19 pandemic was declared a national emergency and compelled the human society to maintain social distancing. This crisis has significantly disrupted the education sector which is a critical determinant of the country's economic future(Jena, 2020). Lockdown and social distancing measures while COVID-19 pandemic have led to closure of schools, colleges, university, training institutes in most of the countries. Consistent with UNESCO monitoring, 192 countries have implemented nationwide closure of academic institutions.(Mukhtar et al., 2020) But this extensive academic institutions closure occurred during an era that has generally been shaped by rapid transformation in technological innovations and digitalization. The online learning, distance and continuing education have become a panacea for this critical situation on COVID-19 pandemic.(Adnan and Anwar, 2020) Also online learning have made the physically challenged students with more freedom to participate requiring limited movement and learning

*Corresponding Author

Dr.Srisakthi Doraikannan,

Department of Public Health Dentistry, Saveetha Dental college, Saveetha Institute of Medical and Technical Sciences, No.162, Poonamallee high road, Chennai 600077, Tamil Nadu, India.

Tel : +918122399966

E-mail: drsrisakthiphd@gmail.com

Received: May 31, 2021

Accepted: July 06, 2021

Published: July 19, 2021

Citation: Sarika Balaganesh, Srisakthi Doraikannan, Meignana Arumugham Indiran. Knowledge, Attitude And Practice Towards Teaching On A Virtual Platform Among Private School Teachers In Chennai. Int J Dentistry Oral Sci. 2021;8(7):3381-3386. doi: http://dx.doi.org/10.19070/2377-8075-21000688

Copyright: Srisakthi Doraikannan 2021. This is an open-access article distributed under the terms of the Creative Commons Attribution License, which permits unrestricted use, distribution and reproduction in any medium, provided the original author and source are credited. 
in virtual platform.(Nambiar, 2020).

Online learning systems are web-based software for distributing, tracking, and managing courses over the Internet. It involves the implementation of advancements in technology to direct, design and deliver the learning content, and to facilitate two-way communication between students and faculty. (Cristina, Petru and Petru, 2017). They contain features such as whiteboards, chat rooms, polls, quizzes, discussion forums and surveys that allow instructors and students to communicate online and share course content side by side. These can offer productive and convenient ways to achieve learning goals(Mukhtar et al., 2020).

Schools in India followed the guidelines of state and union government and initiated virtual classes to bridge the gap and initiated mandatory virtual classes, and thus, teachers are unfailingly sharing their lessons over Skype call, Zoom call, Google hangouts, Microsoft teams or the other virtual class options to stay the training on(Sangeeta and Tandon, 2020). Although COVID-19 pandemic motivated the academic institutions and schools to go online, the question also arises as to whether the teachers are adapted to render classes on a virtual platform. Attempting to " flatten the curve" poses new challenges for academics and sheer urgency with many teachers having been told to transition away from in-person classes(. and Prasad, 2018; Kim, 2020).

The intended purpose of this research seeks to address the teaching on a virtual platform amid the COVID 19 pandemic and how can existing resources of educational institutions effectively transform formal education into online education with the help of virtual classes and other pivotal online tools in this continually shifting educational landscape based on teachers perspective.This research is needed to know the knowledge of teachers towards their confidence in using devices for online classes, engaging the students, how they organize the class and analyse students performance on online classes. This paper also aims in determining the attitude of the teachers towards virtual teaching on likert scale and practice towards online teaching like the tools used by the teachers during online classes and what was a teacher's perspective on online teaching.

\section{Materials And Methods}

\section{Study Design}

Cross sectional study.

\section{Study Area}

Chennai, the capital city of the state of Tamil Nadu.

Tamil Nadu in India has a diverse population of around 4.3 million(Kumar et al., 2015). It is a major cultural, economic and educational center in South India. Chennai holds the second place for literacy among metropolitan city centers in India with a $90.3 \%$ literacy rate(Kumar, 2014). The city has 394 private schools. A survey by the centre for Teacher Accreditation(Centa) in April 2020 revealed that the teachers taking online classes have tripled over the last three months in Chennai(Gass, 'Lee' Gillis and Russell, 2020).

\section{Study Population}

A list of private schools conducting classes through virtual platforms was obtained from the Government of Tamil Nadu District Statistical Hand book Chennai District 2016-2017. Following two-stage cluster sampling 150 teachers were selected from those private schools and the online questionnaire was circulated to them.

\section{Inclusion Criteria}

Private school teachers from the age of 25 - 60 years conducting online classes in Chennai and who were willing to participate in the study

\section{Exclusion Criteria}

Teachers who were not willing to participate.

\section{Ethical Clearance}

- Prior to the start of the study ethical clearance was obtained from the institutional Ethics Committee, Saveetha University.

- The anonymity of the participants was maintained.

\section{Scheduling}

Data collection was scheduled in the month of January and February 2021.

\section{Sampling}

A list of private schools was obtained from the Government of Tamil Nadu District Statistical Hand book Chennai District 20162017.Following two-stage cluster sampling, private higher secondary schools in Chennai were selected from which teachers who were taking online classes were selected. 175 teachers participated in the study and filled the questionnaire in which 25 forms were not completely marked. Therefore 150 teachers were included in this study.

\section{Survey Instrument}

A pre-tested, structured and self administered questionnaire was adapted from questionnaires used previously in studies done by Jinyoung Kim et al(Kim, 2020), and Sarada Vadlamani et al (Vadlamani et al 2016). The survey tool consisted of many parts.

The first section collected demographic information of the participants such as age, gender, educational qualification, teaching experiences.

The second section assessed the participants levels of knowledge regarding conducting an online class.

The third section assessed the participants attitude towards online teaching.

The last section of the questionnaire assessed the practices of teachers on a online platform and also had a question on whether this web based program can be supplemented to the curriculum in future. 


\section{Results}

There were 150 participants who participated in the study in which $60.7 \%$ were females and $39.3 \%$ were males. Out of the school teachers participating $37 \%$ of the population belong to the age group of $31-40$ years, $30 \%$ belonged to the $41-50$ age group $\%$ of the population were females and $38.3 \%$ were male gender (Table 1).Among the teachers who had below 20 years of teaching experience, $30 \%$ of the population answered to make regular announcements, $10 \%$ answered to host weekly synchronous sessions, $8 \%$ answered to give game type activities and $6 \%$ answered to post discussion questions. Among the teachers who had 20 years of teaching experience, $28 \%$ answered to make regular announcements, $6 \%$ to host weekly synchronous sessions, $4 \%$ to give game type activities and 12\% answered to post discussion questions ( $\mathrm{p}$-value $<0.05$ ). For question number 2 , 14 teachers who had below 20 years of teaching experience answered to communicate objectives and expectations 31\% to provide explicit directions with text and videos, $2 \%$ with updating the class calendar and $3 \%$ with easy access to course information, with teaching experience with above 20 years, $10 \%$ of the teachers answered to communicate objectives and expectations, $28 \%$ of the teachers to provide explicit directions, $4 \%$ to update class calendar and $6 \%$ answered to easy access to course information ( $\mathrm{p}$-value-0.4). For question number 3 , in the group of teachers having teaching experience below 20 years answered $20 \%$ of the teachers with monitor students progress, $12 \%$ with assignments, $13 \%$ with online quizzes and $4.6 \%$ to collect formative assessment data( $\mathrm{p}$ value-0.7)(Table 2) .

Table 1: Distribution of study subjects according to age and gender

\begin{tabular}{|c|c|c|c|c|c|c|}
\hline \multirow{2}{*}{$\begin{array}{c}\text { Age groups } \\
\text { (in years) }\end{array}$} & \multicolumn{4}{|c|}{ Gender } & \multicolumn{2}{c|}{ Total } \\
\cline { 2 - 5 } & \multicolumn{2}{|c|}{ Male N (\%) } & \multicolumn{2}{c|}{ Female N (\%) } & \multirow{2}{*}{} & $\%$ \\
\cline { 2 - 6 } & $\mathbf{N}$ & $\mathbf{\%}$ & $\mathbf{N}$ & $\mathbf{\%}$ & & \\
\hline $20-30$ & 8 & $5.5 \%$ & 15 & $10 \%$ & 23 & 15 \\
\hline $31-40$ & 24 & $16 \%$ & 31 & $20 \%$ & 55 & 37 \\
\hline $41-50$ & 14 & $9 \%$ & 31 & $20 \%$ & 45 & 30 \\
\hline$>50$ & 13 & $8 \%$ & 14 & $9 \%$ & 27 & 18 \\
\hline Total & 59 & $39.3 \%$ & 91 & $60.7 \%$ & 150 & 100 \\
\hline
\end{tabular}

Table 2: Distribution of study participants regarding knowledge on virtual teaching

\begin{tabular}{|c|c|c|c|c|c|}
\hline S.No & Questions & $\begin{array}{l}\text { Teaching experience } \\
\text { of } 10-20 \text { years }\end{array}$ & $\begin{array}{l}\text { Teaching experience } \\
\text { above } 20 \text { years }\end{array}$ & $\begin{array}{l}\text { Chi } \\
\text { square } \\
\text { value }\end{array}$ & p-value \\
\hline \multirow{4}{*}{1} & $\begin{array}{l}\text { How did you engage the students in online } \\
\text { teaching? } \\
\text { Make regular announcements }\end{array}$ & $45(30 \%)$ & $43(28.67 \%)$ & \multirow{4}{*}{6.522} & \multirow{4}{*}{0.08} \\
\hline & Post discussion questions & $09(6 \%)$ & $18(12 \%)$ & & \\
\hline & Host weekly synchronous session & $10(6.67 \%)$ & $06(4 \%)$ & & \\
\hline & Give game -type activities & $13(8.67 \%)$ & $06(4 \%)$ & & \\
\hline \multirow{4}{*}{2} & $\begin{array}{l}\text { What are the ways to organise an online class? } \\
\text { Communicate objectives and expectations }\end{array}$ & $22(14.67 \%)$ & $16(10.67 \%)$ & \multirow{4}{*}{3.267} & \multirow{4}{*}{0.4} \\
\hline & Provide explicit directions (text or video) & $47(31.33 \%)$ & $42(28 \%)$ & & \\
\hline & Update class calendar & $03(2 \%)$ & $06(4 \%)$ & & \\
\hline & Easy access to course information & $05(3 \%)$ & $09(6 \%)$ & & \\
\hline \multirow{4}{*}{3} & $\begin{array}{c}\text { How did you analyse the student performance } \\
\text { in online teaching? } \\
\text { Online quizzes }\end{array}$ & $20(13.33 \%)$ & $16(10.67 \%)$ & \multirow{4}{*}{1.405} & \multirow{4}{*}{0.7} \\
\hline & Assignments & $19(12.67 \%)$ & $17(11.33 \%)$ & & \\
\hline & Monitor students progress & $31(20.67 \%)$ & $29(19.33 \%)$ & & \\
\hline & Collect formative assessment data & $07(4.6 \%)$ & $11(7.33 \%)$ & & \\
\hline \multirow{4}{*}{4} & $\begin{array}{l}\text { What are the steps to encourage students to } \\
\text { improve their academic performance? }\end{array}$ & & & \multirow{4}{*}{2.502} & \multirow{4}{*}{0.3} \\
\hline & Good rapport and gestures & $19(12.6 \%)$ & $18(12 \%)$ & & \\
\hline & Give adjustments and accommodations & $18(12 \%)$ & $10(6.67 \%)$ & & \\
\hline & Respond to students in timely manner & $40(26.6 \%)$ & $45(30 \%)$ & & \\
\hline
\end{tabular}


Table 3 Distribution of study participants regarding attitude on virtual teaching

\begin{tabular}{|c|c|c|c|c|c|}
\hline S.No & Questions & $\begin{array}{c}\text { Teaching experience } \\
\text { of } 10-20 \text { years }\end{array}$ & $\begin{array}{c}\text { Teaching experience } \\
\text { above } 20 \text { years }\end{array}$ & $\begin{array}{c}\text { Chi Square } \\
\text { Value }\end{array}$ & p-value \\
\hline \multirow[t]{2}{*}{5} & $\begin{array}{c}\text { Do you feel web based training } \\
\text { should be made available to } \\
\text { supplement teacher? } \\
\text { Yes }\end{array}$ & $31(20 \%)$ & $23(16 \%)$ & \multirow[t]{2}{*}{1.246} & \multirow[t]{2}{*}{0.2} \\
\hline & No & $46(30 \%)$ & $50(33 \%)$ & & \\
\hline \multirow[t]{2}{*}{6} & $\begin{array}{c}\text { Did the students academic } \\
\text { performance improve by online } \\
\text { teaching? } \\
\text { Yes }\end{array}$ & $24(16 \%)$ & $19(12 \%)$ & \multirow[t]{2}{*}{0.484} & \multirow[t]{2}{*}{0.5} \\
\hline & $\mathrm{No}$ & $53(35 \%)$ & $54(36 \%)$ & & \\
\hline \multirow[t]{2}{*}{7} & $\begin{array}{c}\text { What was your perspective on } \\
\text { online teaching? } \\
\text { One way teaching session }\end{array}$ & $24(16 \%)$ & $38(25.33 \%)$ & \multirow[t]{2}{*}{6.741} & \multirow[t]{2}{*}{$0.00^{*}$} \\
\hline & Interactive sessions & $53(35.33 \%)$ & $55(23.33 \%)$ & & \\
\hline \multirow[t]{3}{*}{8} & $\begin{array}{c}\text { How was the behaviour of the } \\
\text { students in E-teaching? } \\
\text { Good }\end{array}$ & $25(16 \%)$ & $52(14 \%)$ & \multirow[t]{3}{*}{0.095} & \multirow{3}{*}{0.7} \\
\hline & Fair & $22(34 \%)$ & $51(34 \%)$ & & \\
\hline & Poor & 0 & 0 & & \\
\hline
\end{tabular}

Table 4: Distribution of study participants regarding practice of online teaching

\begin{tabular}{|c|c|c|c|c|c|}
\hline S.NO & Questions & $\begin{array}{c}\text { Teaching experience } \\
\text { of } 10-20 \text { years }\end{array}$ & $\begin{array}{l}\text { Teaching experience } \\
\text { above } 20 \text { years }\end{array}$ & $\begin{array}{c}\text { Chi Square } \\
\text { Value }\end{array}$ & p-value \\
\hline \multirow{5}{*}{9} & $\begin{array}{c}\text { "Which device did you use } \\
\text { for online classes? } \\
\text { Laptop/ Desktop" }\end{array}$ & $15(10 \%)$ & $14(9 \%)$ & \multirow{5}{*}{8.745} & \multirow{5}{*}{$0.05^{*}$} \\
\hline & Smartphone & $40(26 \%)$ & $51(34 \%)$ & & \\
\hline & $\begin{array}{l}\text { Laptop/Desktop, } \\
\text { Smartphone }\end{array}$ & $19(12 \%)$ & $8(5 \%)$ & & \\
\hline & $\begin{array}{l}\text { "Smartphone,Ipad } \\
\text { /Tablet" }\end{array}$ & 1 & 0 & & \\
\hline & All devices & $2(1.3 \%)$ & 0 & & \\
\hline \multirow{5}{*}{10} & $\begin{array}{c}\text { "What was the application } \\
\text { you used for conducting } \\
\text { classes? } \\
\text { Skype" }\end{array}$ & $1(0.67 \%)$ & $3(2 \%)$ & \multirow{5}{*}{18.98} & \multirow{5}{*}{$0.00^{*}$} \\
\hline & Zoom & $50(33 \%)$ & $36(24 \%)$ & & \\
\hline & Google meet & $15(10 \%)$ & $5(3 \%)$ & & \\
\hline & Whatsapp call & $6(4 \%)$ & $24(16 \%)$ & & \\
\hline & Other Apps & $5(3 \%)$ & $5(3 \%)$ & & \\
\hline \multirow[t]{3}{*}{11} & $\begin{array}{c}\text { "How many hours you spent } \\
\text { in E -teaching per day? } \\
1-3 \text { hours" }\end{array}$ & $32(21 \%)$ & $40(26 \%)$ & \multirow[t]{3}{*}{2.630} & \multirow[t]{3}{*}{0.1} \\
\hline & 3-6 hours & $45(30 \%)$ & $33(22 \%)$ & & \\
\hline & 6-9 hours & 0 & 0 & & \\
\hline
\end{tabular}


Table 5: Association of teaching experience and practice of teaching via online platforms

\begin{tabular}{|c|c|c|c|c|c|}
\hline \multirow[b]{2}{*}{ Practice } & \multicolumn{2}{|c|}{ Teaching experience } & \multirow[b]{2}{*}{ Total } & \multirow{2}{*}{$\begin{array}{l}\text { Chi square } \\
\text { value }\end{array}$} & \multirow[b]{2}{*}{$P$ value } \\
\hline & $\begin{array}{l}10-20 \text { years of } \\
\text { experience }(\%)\end{array}$ & $\begin{array}{c}\text { More than } 20 \\
\text { years of experience }(\%)\end{array}$ & & & \\
\hline Inadequate practice & $22(34.92)$ & $41(65.08)$ & 63 & \multirow{3}{*}{$11.712 \mathrm{a}$} & \multirow{3}{*}{0.001} \\
\hline Adequate practice & $55(63.21)$ & $32(36.79)$ & 87 & & \\
\hline Total & 77 & 73 & 150 & & \\
\hline
\end{tabular}

For attitude questions, the teachers were asked about their perspective of online teaching for which teachers with experience below 20 years answered that $16 \%$ had one way teaching sessions and $35 \%$ answered it was an interactive session and the group of teaching experience above 20 years answered $25 \%$ with one -way teaching sessions and $23 \%$ with interactive sessions and the association was significant with p-value $<0.05$ (Table 3).

For questions on practice, $26 \%$ teachers with teaching experience below 20 years and 34\% teachers with more than 20 years of teaching experience answered that they were using Smartphone ( $\mathrm{p}$-value $<0.05)$ and for the question which application was used the most, $33 \%$ teachers with teaching experience below 20 years and $24 \%$ teachers with more than 20 years of teaching experience answered that they were using zoom call ( $\mathrm{p}$-value $<0.05)$ (Table 4).

There was a significant association between the teaching experience of the teachers and their practice of teaching through online platforms. $(p<0.05)$ (Table 5).

\section{Discussion}

The acquaintance of online teaching during COVID-19 pandemic was a step indeed to exploit the potential of technology for schools by keeping the safety of students and teachers without wasting their academic hours (Kim, 2020). Majority of the private higher secondary schools initiated virtual classes and teachers were sharing their lessons through Skype call, Zoom call and other virtual platforms(Sangeeta and Tandon, 2020). This was similar to the results of a similar study in Indonesia in 2020 (Aliyyah et al., 2020).

In the present study, teachers with less than 20 years of experience had interactive sessions and teachers with teaching experience above 20 years had a one way teaching session. Similarly in a study, the teachers told they use videos for the online teaching. (Aliyyah et al., 2020). Similarly from the students perceptive, they want a interactive learning than one way learning (Dhawan, 2020).

In the current study, smartphones were the most used device among both groups followed by laptop/desktop. Similarly, smartphones were predominantly used (Anis, 2020). Also in the present study, Zoom call was the application used predominantly by both the groups, this is similar to the study conducted in Indonesia (Assapari and Mugni Assapari, 2021).

Previous studies stated that there was a significant association on behaviours and feelings of students on their behaviour while attending online classes, mostly the students disagree to the state- ment and said that they behaved well which was also similar with the current study $34 \%$ of the teachers answered that students behaviour was better in online classes in both the teachers group(Zhao et al., 2020).

In the present study, teachers expressed that there was only 3-6 hours of online class per day, similarly in a study conducted in China, the sleeping time was 8 hours for the students attending online classes and only they spent 3 to 4 hours for online classes. (Song, Wu and Zhi, 2020).

Another study also stated that social influence had insignificant relationship with behavioural intention and attitude had a significant impact on the behavioural intention. This study found that performance expectancy and facilitating conditions had a positive impact on behavioural intention as well as attitude (Sangeeta and Tandon, 2020; Song, Wu and Zhi, 2020). In the study done by Teo \& Noyes 2014, seniority of the teachers and length of service plays a vital role in shaping the attitude toward the technology (Basilaia and Kvavadze, 2020; Lestari and Gunawan, 2020).

\section{Implications Of The Study}

The findings of the current study provide significant implications to the policy makers of the school to implement online teaching to improve and facilitate the students academic performance at the time of pandemic outbreak.

The study had few limitations, the study draws samples only from chennai, future studies may replicate the study in the remaining part of tamilnadu as exposure to technology varies in different parts of the state.

\section{Conclusion}

The study determined various perspectives from the school teachers about teaching on a virtual platform. The study concluded that more than half of the participants had sufficient knowledge,but majority of them had a positive attitude and had adequate practice on teaching on online platforms. This study proves that adequate training should be provided even to the teachers for teaching via online platforms.

\section{References}

[1]. Adnan M, Anwar K. Online Learning amid the COVID-19 Pandemic: Students' Perspectives. Online Submission. 2020;2(1):45-51.

[2]. Aliyyah RR, Rachmadtullah R, Samsudin A, Syaodih E, Nurtanto M, Tambunan AR. The perceptions of primary school teachers of online learning during the COVID-19 pandemic period: A case study in Indonesia. Journal of Ethnic and Cultural Studies. 2020 Aug 1;7(2):90-109. 
[3]. Anis SN, Ibrahim MA, Tahir LM, Abu B, Khan A, Aziz RA. COVID 19 and campus experience: Survey on online learning and time spent during the movement control order (MCO) among Malaysian postgraduates. Journal of Advanced Research in Dynamical and Control Systems. 2020:2929-33.

[4]. Assapari MM. THE CHALLENGES OF TEACHING EFL FOR ADULT LEARNERS: ONLINE LEARNING DURING THE COVID-19 PANDEMIC. Jurnal Ilmiah Spectral. 2021 Jan 31;7(1):011-28.

[5]. Basilaia G, Kvavadze D. Transition to online education in schools during a SARS-CoV-2 coronavirus (COVID-19) pandemic in Georgia. Pedagogical Research. 2020;5(4).

[6]. Cristina G, Petru T, Petru V. The quality of online courses in the students perception. In2017 International Conference on Electromechanical and Power Systems (SIELMEN) 2017 Oct 11 (pp. 341-346). IEEE.

[7]. Dhawan S. Online learning: A panacea in the time of COVID-19 crisis. Journal of Educational Technology Systems. 2020 Sep;49(1):5-22.

[8]. Gass MA, Russell KC. Adventure therapy: Theory, research, and practice. Routledge; 2020 Mar 11.

[9]. Jena PK. Impact of pandemic COVID-19 on education in India. International Journal of Current Research (IJCR). 2020 Jul 30;12.

[10]. Kim J. Learning and Teaching Online During Covid-19: Experiences of Student Teachers in an Early Childhood Education Practicum. Int J Early Child. 2020 Jul 30:1-14. Pubmed PMID: 32836369.

[11]. Kumar A, Kumar N, Baredar P, Shukla A. A review on biomass energy resources, potential, conversion and policy in India. Renewable and sustainable energy reviews. 2015 May 1;45:530-9.
[12]. Kumar J. Progress of urban literacy in India: Focus on Metropolises.

[13]. Lestari PA, Gunawan G. The Impact of Covid-19 Pandemic on Learning Implementation of Primary and Secondary School Levels. Indonesian Journal of Elementary and Childhood Education. 2020 Jun 30;1(2):58-63.

[14]. Mukhtar K, Javed K, Arooj M, Sethi A. Advantages, Limitations and Recommendations for online learning during COVID-19 pandemic era. Pak J Med Sci. 2020 May;36(COVID19-S4):S27-S31. Pubmed PMID: 32582310.

[15]. Nambiar D. The impact of online learning during COVID-19: students' and teachers' perspective. The International Journal of Indian Psychology. 2020;8(2):783-93

[16]. Sarada Vadlamani et al (2016).

[17]. Sangeeta, Tandon U. Factors influencing adoption of online teaching by school teachers: A study during COVID-19 pandemic. J Public Aff. 2020 Oct 14:e2503. Pubmed PMID: 33173442.

[18]. Song H, Wu J, Zhi T. Results of Survey on Online Teaching for Elementary and Secondary Schools During COVID-19 Prevention and Control. ECNU Review of Education. 2020:2096531120930021.

[19]. S. and Prasad, K. N. A cross sectional study on health seeking behavior of migrant workers: Bangalore city, International Journal Of Community Medicine And Public Health, 2018;p. 1653.

[20]. Zhao Y, Guo Y, Xiao Y, Zhu R, Sun W, Huang W, et al. The Effects of Online Homeschooling on Children, Parents, and Teachers of Grades 1-9 During the COVID-19 Pandemic. Med Sci Monit. 2020 Sep 12;26:e925591. Pubmed PMID: 32917849. 